Nairobi : Government Printer, 1950; 2s. 6d.). The author gives a brief description of Kenya Colony, with an area of 219,700 sq. miles, of which only one-third has a soil and climate suitable for normal human habitation. The south-western third of the Colony is made up of the Highlands, about one-tenth of which, that is, about 6,500 sq. miles, is believed to be forest. Although the climate of the Highlands is of a tropical nature, it has widely different extremes ranging from the alpine flora of snow-capped Mount Kenya to semi-tropical rain forest in the Lake Victoria basin. There are then two main divisions of forest in the Highlands : mountain forests which are made up of rain, coniferous, bamboo, and semievergreen forests ; and semi-tropical rain forests. Inaddition, there are the lowland or coast forests comprising low and rain forest, lowland dry forest and lowland savanna woodland. Brief notes on the characteristics of these forest types are followed by a few general notes on Kenya timbers. Finally, there are indexes to botanical, English and trade names, and to native names with the botanical equivalents. The main purpose of the handbook is achieved, the trees mentioned being given alphabetically with the following details: local names, distribution, frequency, the timbers and uses. Handbooks of this type are invaluable to all forest officers working in tropical areas.

\section{Industrial Microscopy}

AN exhibition of "How Industry is Using the Microscope" has been arranged by the Royal Microscopical Society (Industrial Section), to be held on November 21 in the Great Hall, British Medical Association House, Tavistock Square, London, W.C.1, by kind permission of the British Medical Association. The exhibition will be opened by Mr. A. J. Philpot, director of the British Scientific Instruments Research Association, at 2.30 p.m., and will remain open until 9.30 p.m. Some forty exhibitors are taking part, including research associations and university departments as well as the research departments of a number of industrial firms and the Department of Scientific and Industrial Research. The exhibits cover a wide range and can be classified as concerning: mining and power ; metallurgy ; glass and ceramics ; paint; paper, rubber and fabrics (including leather); photography; food and agriculture; pharmacy ; biology. The various modern forms of optical microscopy are represented in addition to electron microscopy. Apparatus and techniques of general and special application are being demonstrated as well as surface profile techniques for electron microscopy. The exhibition is well illustrated by photomicrographs and electron micrographs. It is open to all, and the catalogue of exhibits and further information can be obtained from the Assistant Secretary, Royal Microscopical Society, Tavistock House South, Tavistock Square, London, W.C.I.

\section{Royal Society of Edinburgh : Officers}

OFFICE-BEARERS and members of council of the Royal Society of Edinburgh have been elected as follows : President, Prof. James Kendall ; VicePresidents, Prof. Arthur Holmes, Prof. W. O. Kermack, Prof. E. T. Copson, Prof. J. H. Gaddum, Sir Robert Muir and Prof. James Ritchie; General Secretary, Dr. J. E. Richey ; Secretaries to Ordinary Meetings, Prof. J. Norman Davidson and Dr. John E. Mackenzie; Treasurer, A. W. Young; Curator of Library and Museum, Dr. Douglas Guthrie; Coun- cillors, Prof. T. Neville George, Prof. J. W. Heslop Harrison, Dr. C. E. Lucas, Prof. M. G. Say, Prof. W. M. Smart, Prof. J. F. Allen, Prof. A. Murray Drennan, Dr. E. Wyllie Fenton, J. M. Ross, Prof. C. M. Yonge, Prof. N. Feather and Sir Godfrey Thomson.

\section{Announcements}

CAPt. Cyril DIver, director-general of the Nature Conservancy, is to retire next autumn. A small committee under Sir Arthur Tansley, chairman of the Conservancy, is considering the problem of finding a successor to Capt. Diver.

Mr. S. S. C. Mrtcereli has been appointed controller of guided weapons and electronics in the Ministry of Supply, in succession to Air Chief Marshal Sir Alec Coryton. Mr. Mitchell, who is forty-nine years of age, will be in charge of all work in research, development and production of guided weapons in Britain. He will also undertake responsibility for the direction of the Ministry of Supply's work on electronics research, development and production.

DR. A. H. BONTING, who held until recently the post of chief scientific officer with the Overseas Food Corporation (see p. 804), and who was responsible, from the inception of the groundnut scheme in Tanganyika in 1947, for the agricultural research services there, has been appointed to the Research Division of the Sudan Ministry of Agriculture. He is to be in charge of a new research station for investigating the agricultural potentialities of the central rainlands area of the Sudan. Dr. Bunting was trained at Johannesburg and Oxford (as Rhodes Scholar for the Transvaal, 1938) and has held appointments at Rothamsted Experimental Station, and with the Human Nutrition Research Unit of the Medical Research Cotancil.

THE .Department of Scientific and Industrial Research (Charles House, 5-11 Regent Street, London, S.W.1) is holding an international symopsium on the organization of scientific and industrial research, which will take place in London during November 12-15. All sessions will be held in the Council Room, Lancaster House, London, S.W.I, with the exception of the third session, on "Sponsored Research", which will be held at the National Physical Laboratory, Teddington. Representatives from the following countries will be attending the symposium : Austria, Belgium, Canada, Denmark, France, Germany, Greece, Ireland, Italy, Netherlands, Norway, Sweden, Switzerland and the United States.

THe Science Section of the Society for Cultural Relations between the Peoples of the British Commonwealth and the U.S.S.R. has arranged a moeting to be held in the Anatomy Theatre, University College, London, W.C.I, on November 16 at 7 p.m. on "Some Aspects of Biological Research in the Soviet Union, 1948-1951". The chairman is Dr. Sidnie Manton, and other speakers are: Dr. A. Morton on "The Role of Environment in Plant Development"; Dr. R. Trim on "Enzymes and the Living Cell"; Dr. D. Ross and Mr. D. Newth "On Animal Embryos and Cells" ; Prof. J. D. Bernal on "Relation between Living and Non-living Matter". Tickets of admission (1s. ; S.C.R. members $6 d$.) can be obtained from the Society, 14 Kensington Square, London, W.8. It is hoped that this meeting may lead to regular annual surveys of Russian work in specific fields. 